\title{
Cost And Price Relation According To Milk / Feed Parity: (Turkey 2010-2015)
}

\author{
Ibrahim Emre Göktürk ${ }^{1}$, H.Serdar Yalçinkaya ${ }^{2}$ \\ ${ }^{1}$ Asst.Prof.Dr, Necmettin Erbakan University, \\ ${ }^{2}$ Asst.Prof.Dr, Necmettin Erbakan University,
}

\begin{abstract}
Since the milk is the main food source of healthy nutrition and every kinds of development of individuals from the early ages onward, today it is consumed by millions of people and corollary to this sector of dairy products has an important place in the world economy. The recent developing technologic and economic transformations caused to the development of sector and thus to the increase of competition. In order to follow the changes and hold the competitive power, sector firms whose capital costs are increasing have to produce their products in high quality and low costs. Likewise, instant changes in the supply and demand of milk productions also show the importance of future planning in the sector. The aim of this paper is to identify the financial relationship between the cost items which constitute the production costs in the production of milk. Monthly data of 2010-2015 in Turkey is used. The relationship of fodder which are one of the most important raw materials with milk prices are examined by using month data of 2010-2015 in the single equation model and the structural refraction times in the periods are identified. Through these structural breaking times, relationship between the milk costs and sale prices are analyzed. In the analyses a meaningful relation between milk prices and production items is not found, while structural refraction is identified in the two different periods.
\end{abstract}

Keywords: Fodder Costs, Milk Production, Milk Prices, Artificial Refraction

\section{Introduction}

As well as being a main protein source; milk, as a basic raw material, used also in food industry is supplied from animals such as cattle, buffalo, sheep, goat, mandate, camel etc. [9]. Milk and milk products that are a value chain consisting of numerous actors starting from animal breeder to the final user are taken from breeders, collected in milk collecting facilities and factories and presented to consumers after being pasteurized within production process and made natural milk and various milk products.Depending on increasing population and national income in developing countries, besides developed countries, consumption of milk and milk-based products, as important nutritional sources and one of the basic food needs for people, has been increasing recently. Again, depending on the increase in demand, it is seen that milk industry that is a significant commercial commodity in the world economy, also expands and develops [3]

Raw milk production is carried out by breeders and manufacturing enterprises for that reason. The most important income of breeders and companies is obtained from milk sales and the most important cost element is feed prices [16] . Because of being a perishable product and high cost of stocking, milk productions that are determined by national and international milk demands of countries are controlled with milk sale prices. While determining a suitable milk sale price in the world, raw milk/feed parity is used. To control the milk demand in Turkey that is amongst the ten countries for the world milk production, the National Dairy Council was established in 2008. The National Dairy Council determines the top price of raw milk sale in six-month period [26]. Input cost for milk industry expected from the National Dairy Council is the determination of milk sale price which is an income item for producers.In our study, the relation between the determined sale prices between 2010 and 2015 and feed prices in free market conditions was analysed with single-equation model and structural breaking times between the periods were determined. In line with the importance of planning for future of the milk sector and to be able to realise milk producers' planning more effectively; producers that carry out production of the sector must create effective sale price policies in order to sustain benefit continuity in terms of future investment and determination of production policies. For that reason, the determination of sale prices to be created on input costs will be the most important element to provide a continuous growth. This study is considered to be useful in terms of the determination of an effective sale price.

\section{Milk Production In Turkey And The World}

Along with the removal of commercial barriers and increasing globalization of the world milk production sector, scope and intensity of milk product production in commercial sense have also increased. According to FAO data, the world milk production amount has reached up to 769 million tonnes with $50 \%$ percent increase from 500 million tonnes in the last three decades. $60 \%$ of the world milk production is met by 10 countries, including Turkey. 
Figure 1: Countries Meeting 60\% Of The World Milk Production

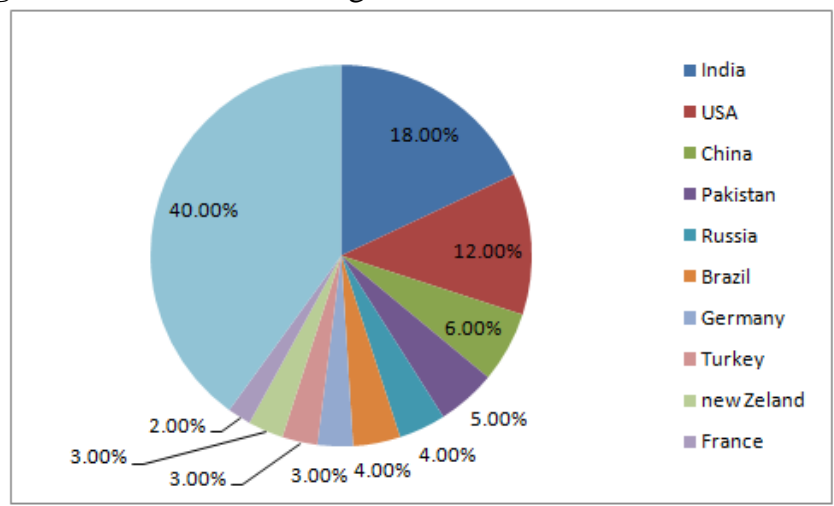

Source: PMMI, 2013, Executive Summary and Industry Perspective, 2013 Dairy Industry - A Market Assessment Executive Summary p.3

As the important milk producers, India meets $18 \%$ of the world milk production, while U.S.A. takes $12 \%$ and China holds $6 \%$. The world milk production as of 2020 is targeted to be 830 million tonnes. [19] Turkey meeting $3 \%$ of the world milk production had total production of around 18.223.712 tonnes according to 2014 data [26]; [6]; [22]. Although Turkey has an important share in milk production in the world, it faces with certain problems in terms of the sector. These problems are;

- Development of available races that milk producers have and outputs gained from these are not at the desired level depending on the circumstances of undernourishment and adverse maintenance conditions. Not enough culture race or cross breeding are being used [7].

- $\quad 47 \%$ of the milk produced in Turkey is transferred to the industry. In that case, it can be said that there is about 50\% unrecorded milk production [5]; [2] Unrecorded milk production is a huge obstacle for creation of future macro policies.

- The most important problem in raw milk production in Turkey is milk's characteristic of being a perishable product. Milk must be sold very quickly as storing costs too much [27]. Milk sellers will have to sell their products with the price determined in this process or a lower price as it goes unsold [29].

- While milk amount that is put on the market in developed countries is $98 \%$, only $60 \%$ of the milk produced in Turkey is offered for sale, $25 \%$ is consumed in production units, $10 \%$ is used in animal breeding and animal development and the rest $5 \%$ goes to waste [1]

\section{Milk Consumption In Turkey And The World}

Milk production in the world varies according to consumption habits of regions, climate, agricultural variety and population. While consumption is high in countries in Europe and Oceania, it is seen that the consumption is at the low levels in Asia and Africa [8].According to FAO, total milk consumption in the world is distributed as $41 \%$ in Asia, $27 \%$ in Europe. Countries whose annual milk consumption per capita is over 150 kg are Argentina, Armenia, Australia, Costa Rica, European countries, Israel, Kyrgyzstan, North America and Pakistan, and countries with 30-150 kg annual milk consumption per capita are India, Iran, Japan, Kenya, Mexico, Mongolia, New Zealand, North and South Africa, large part of the near east and Latin America and Caribbean islands. And countries that have under $30 \mathrm{~kg}$ annual milk consumption per capita are Vietnam, Senegal, Central Africa and large part of the East and Southeast Asia [8].

Figure 2: Annual Milk Consumption Per Capita in the World (kg)

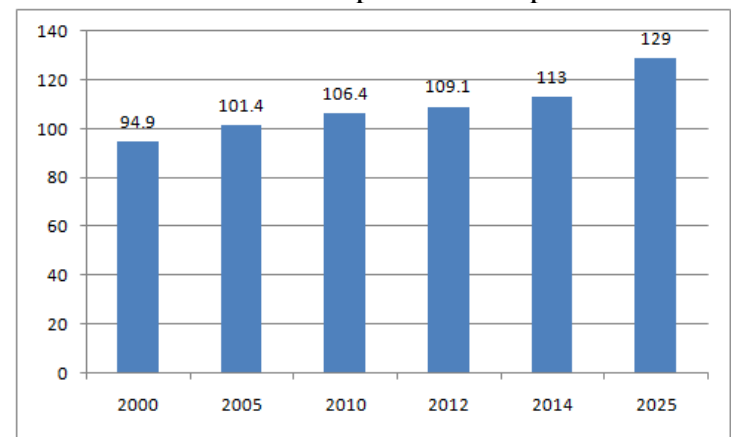

Source: IDF, 2013 The World Dairy Situation, Bullet Of The International Dairy Federation 470 Belgium , S.5 and FAOSTAT 
Milk consumption per capita in the world in 2010 was 106,4; 109,1 in 2012 and around $113 \mathrm{~kg}$ in 2014. The value is expected to be $129 \mathrm{~kg}$ per capita in 2025 [12]. In line with the data of the National Dairy Council, milk consumption per capita in Turkey is $37,3 \mathrm{~kg}$, which is way below the world average. The fact that Turkey that is an important milk producer does not get enough demands in the domestic market sets forth a production necessity for export [5] Besides export, milk consumption in Turkey to be able to protect milk supply elasticity must be encouraged and domestic market must be boosted. In consequence of the fact that developing countries have not reached the satisfaction level for food of animal origin, milk consumption will increase depending on income increase and in a sense, socio-economic structures of consumers, like other food products, will increase milk consumption [25]. In the future, depending on income increase, milk demand is expected to increase in developing countries [3]. In that case, milk production sector will gain importance and also milk consumption in the next 15 years is expected to increase in Asian countries, especially in south Asia, with $125 \%$ rate [8].

\section{Milk Sale Price - Relation Of Feed Prices And Milk/Feed Parity}

In order to carry out future plans of breeders and enterprises that produce milk, they need to have knowledge about income and expense structures and it is so important for them to know in which periods these information show an alteration. However, one of the most important problems in terms of enterprises that produce milk having these kind of information is the insufficient information of financial information, namely inadequacies in data entry structure. Enterprises can not organize enough data layout related to activities starting from production process to sale. Estimation of income costs and determination of necessary sale prices for the future are important for real-like calculation of benefit values. Especially, not being able to calculate input costs completely reveals the necessity to act according to environmental market price formations and that causes malcalculation of benefit numbers gained from post-sale of individuals or enterprises whose input costs are high.

Table 1: Milk Prices Of Countries in Annual Basis

\begin{tabular}{|l|l|l|l|l|}
\hline Milk Prices Euro / KG & 2012 & 2013 & 2014 & 2015 \\
\hline Years & 0,306 & 0,308 & 0,385 & 0,272 \\
\hline Belgium & 0,316 & 0,338 & 0,382 & 0,276 \\
\hline Germany & 0,318 & 0,291 & 0,383 & 0,27 \\
\hline Denmark & 0,393 & 0,365 & 0,405 & 0,386 \\
\hline Finland & --- & ----- & 0,278 & 0,293 \\
\hline Argentina & --- & 0,443 & 0,495 & 0,495 \\
\hline China & ---- & ----- & 0,39 & 0,31 \\
\hline Russia & 0,339 & 0,304 & 0,395 & 0,309 \\
\hline France & 0,329 & 0,318 & 0,372 & 0,331 \\
\hline Britain & 0,322 & 0,293 & 0,365 & 0,279 \\
\hline Ireland & 0,337 & 0,306 & 0,389 & 0,271 \\
\hline Netherlands & 0,305 & 0,246 & 0,378 & 0,23 \\
\hline New Zealand & 0,308 & 0,295 & 0,356 & 0,316 \\
\hline USA. & 0,294 & 0,281 & 0,281 & 0,314 \\
\hline South Africa & $\mathbf{0 , 3 2 4}$ & $\mathbf{0 , 3 1 6}$ & $\mathbf{0 , 3 7 5}$ & $\mathbf{0 , 3 1 1}$ \\
\hline WORLD AVERAGE & $\mathbf{0 , 3 6 7}$ & $\mathbf{0 , 3 7 5}$ & $\mathbf{0 , 3 6 8}$ & $\mathbf{0 , 3 8}$ \\
\hline Turkey & & &
\end{tabular}

Source: LACTODATA (2015), statistics, A milk SA publication compiled by the Milk Producers organizastion, Vol $18 \cdot$ No $1 \cdot$ May, http://www.clal.it and National Dairy Council

Milk price that was $0,324 €$ in 2012 increased to $0,316 €$ in 2013 and to $0,375 €$ in 2014 with the increase in milk [15] import after melamine had been found in Chinese infant formula and with the effect of the increase in global milk demand depending on the drought emerged in New Zealand [17]. Excess supply that was emanated after Russia's quota application on cheese import and diminishment in negative situations in China and New Zealand as well as increase in milk supply related to meet the demand in 2013 and 2014, caused milk prices to be reduced down to $0,311 €$ with the price withdrawal [18]. Owing to the inconsistency in international milk supply and demand, controlling of excess supply in the countries where this excess supply exists is performed with sale prices and milk quotas against domestic demands. Milk supply is provided by predetermined sale price policy in Turkey. The National Dairy Council predicates the feed prices on and determines milk price/feed price parity for milk sale prices and fixes the milk prices in 6-month periods [26].

When sale prices determined by the NDC in Turkey between the years 2012-2015 are examined, it is seen that milk sale prices are higher than the world average except for 2014. Two important details related to milk prices in Turkey stand out in Table 1. The first is that there was no significant change in milk prices in Turkey in spite of the global crisis in 2014. That creates the impression that the NDC actually provided the price consistency. The second is that the prices determined by the NDC in Turkey, except for 2014, were over the world average. The most important problem for milk producers in Turkey lately is considered not being able to increase milk sale prices at a desired level in relation to input costs. While milk sale prices are determined in a controlled way 
by the National Dairy Council established in the early of 2009 in Turkey, the most important input cost has been feed prices in the free market conditions. In order to better understand input costs of milk producers, comparison of feed prices in Turkey and the world will be useful. Comparison of feed prices in the world market with feed prices against milk prices in terms of milk producers is given in Table 2.

Table 2: Comparison of Average Feed Prices in Turkey and the World - 2010-2016 Euro/Kg

\begin{tabular}{|l|l|l|l|l|l|l|l|}
\hline & 2010 & 2011 & 2012 & 2013 & 2014 & 2015 & 2016 \\
\hline $\begin{array}{l}\text { WORLD } \\
\text { AVERAGE }\end{array}$ & 0,169 & 0,228 & 0,272 & 0,243 & 0,206 & 0,203 & 0,180 \\
\hline Turkey & 0,245 & 0,271 & 0,307 & 0,287 & 0,261 & 0,254 & ----- \\
\hline
\end{tabular}

Source: IFCN, Dairy Report 2015, SETBİR, TYSB

As seen In Table 2, average feed price was $0,169 €$ in 2010 , increased to $0,272 €$ in 2012 and decreased to $0,243 €$ in 2013 and continued to decrease to $0,206 €, 0,203 €$ in 2015 and finally $0,180 €$ as of the first quarter of 2016. When the average feed price in Turkey is considered, it is seen that the price was $0,245 €$, increased to $0,307 €$ in 2012 and decreased to $0,243 €$ in accordance with the trend in the world as of 2013 and was $0,261 €$ in 2014 then decreased to $0,254 €$ in 2015 . When considered in general, it is seen that the average feed prices in Turkey have been higher than the world average. [20];[23] The most important input for milk producers is constituted by feed prices. In fact, in determination of milk sale prices in the whole world, generally accepted calculation is the question of how many kilograms of feed corresponds to $1 \mathrm{~kg}$ milk production, which is called milk-feed parity [28]. Well accepted milk-feed parity in the world is 1,5 [13]. Comparison of the AEPDI and the NDC parity with milk-feed parity generated in line with our values is given in Table 3.

Table 3: Milk-Feed Parity in Turkey between the years 2012-2015

\begin{tabular}{|l|l|l|l|l|}
\hline & $\mathbf{2 0 1 2}$ & $\mathbf{2 0 1 3}$ & $\mathbf{2 0 1 4}$ & $\mathbf{2 0 1 5}$ \\
\hline B $^{*}$ & 1,26 & 1,28 & 1,36 & 1,47 \\
\hline C $^{* *}$ & 1,02 & 1,11 & 1,18 & 1,21 \\
\hline
\end{tabular}

* Average rate of Agricultural Economics and Policy Development Institute found that the rate [24]

**Average rate declared by the National Dairy Council (www.ulusalsutkonseyi.org.tr/ana/fiyat.asp?uid=40)

The values we gained match up with the AEPDI data. [24]. The parity determined by the NDC, however, is quite low. This leads milk prices to be determined as lower than they should be. There are probably certain reasons for this. Whether milk sale prices determined by the NDC change at the same rate with feed costs will be examined via an analysis we will have.

\section{Methodology}

Monthly price values between the years 2010-2015 of production factors that are considered to be influential in constitution of milk prices were used in the analyses as 72 periods. Also, ppi (producer price index) that was declared in the period and USD \$ were used in the analyses to see their effects on the prices. In accordance with this data structure, the first micro determinant item to milk prices is seen to be material prices while the macro determinant was ppi and USD \$. Data set created is shown in appendix 1.Double-equation regression analysis will be conducted between milk prices and micro determinants. However, due to the fact that the data set is actually a time-series, logarithms of the data were taken to enable analyses to be able to give significant results. Model generated can be seen below:

The regression analysis made after the determined model is given in Table 4.

Table 4: Results of the Regression Analysis

\begin{tabular}{|l|l|l|l|l|}
\hline \multicolumn{2}{|l|}{ DependentVariable: LSUT } & & \\
\hline \multicolumn{2}{|l|}{ Method: LeastSquares } & & \\
\hline Date: 03/07/16 Time: 12:35 & & \\
\hline \multicolumn{2}{|l|}{ Sample: 2010M01 2015M12 } & & \\
\hline Includedobservations: 72 & Coefficient & Std. Error & t-Statistic & Prob. \\
\hline Variable & -0.818988 & 0.321153 & -2.550146 & 0.0131 \\
\hline LYEM & 1.420675 & 0.201975 & 7.033928 & 0.0000 \\
\hline LBUGDAY & -0.183498 & 0.232174 & -0.790350 & 0.4322 \\
\hline LARPA & -0.457315 & 0.185421 & -2.466365 & 0.0163 \\
\hline LMISIR & 0.611622 & 0.187772 & 3.257258 & 0.0018 \\
\hline LSOYA & 2.825021 & 0.595356 & 4.745097 & 0.0000 \\
\hline C & 0.737648 & Meandependent var & 6.799168 \\
\hline R-squared & & & \\
\hline
\end{tabular}


Cost And Price Relation According To Milk / Feed Parity: (Turkey 2010-2015)

\begin{tabular}{|l|l|l|l|}
\hline Adjusted R-squared & 0.717773 & S.D. dependent var & 0.191856 \\
\hline S.E. of regression & 0.101924 & Akaikeinfocriterion & -1.649528 \\
\hline Sumsquaredresid & 0.685638 & Schwarzcriterion & -1.459806 \\
\hline Loglikelihood & 65.38300 & Hannan-Quinncriter. & -1.573999 \\
\hline F-statistic & 37.11417 & Durbin-Watson stat & 0.359830 \\
\hline Prob(F-statistic) & 0.000000 & & \\
\hline
\end{tabular}

As a result of the regression model generated via logarithms of the variables, it is seen that there is a significant relation between milk prices and micro determinants, except for barley. The model generated can explain our problem according to $\mathrm{R}^{2}$ values and confidence interval of the model is accepted as statistically significant $(\mathrm{P}<0,05, \mathrm{~F}<0,05)$. But because the data set is time-series and because of the high $R^{2}$ value $\left(R^{2}=\right.$ 0.717773), stability problem in the model is entitled to be researched [10]. In the case of using instable series in the regression analysis, it is possible to get significant regression results in a misleading way from the data that are unrelated to each othe [14]. In order to determine the stability of the data, ADF (Augmented Dickey-Fuller) Unit-Root Test was used.

Table 5: ADF Unit-Root Test Results

\begin{tabular}{|l|l|l|l|l|}
\hline \multirow{2}{*}{} & \multicolumn{3}{|l|}{$\begin{array}{l}\text { Yüzey Seviyesinden ADF } \\
\text { sonuçları }\end{array}$} & \multicolumn{2}{l|}{$\begin{array}{l}\text { 1. Fark Seviyesinden ADF } \\
\text { sonuçları }\end{array}$} \\
\cline { 2 - 5 } & t test & prob. & t test & prob. \\
\hline Süt & -0.323102 & 0.9154 & -7.759 .926 & 0.0000 \\
\hline Yem & -2.864 .527 & 0.0547 & -6.644 .183 & 0.0000 \\
\hline Soya & -2.259 .568 & 0.1878 & -6.403 .887 & 0.0000 \\
\hline Mısır & -2.389 .593 & 0.1483 & -5.335 .316 & 0.0000 \\
\hline Arpa & -2.438 .303 & 0.1352 & -6.436 .934 & 0.0000 \\
\hline Buğday & -1.654 .822 & 0.4495 & -4.839 .857 & 0.0002 \\
\hline Dolar(\$) & 0.686870 & 0.9911 & -6.670 .022 & 0.0000 \\
\hline ÜFE & -1.232 .346 & 0.6560 & -5.732 .043 & 0.0000 \\
\hline
\end{tabular}

As seen in Table 5, ADF (Augmented Dickey- Fuller) unit-root test was carried out. According to the unit-root analysis results, stability problem in all variables was confirmed. When first degree differences of the variables are calculated, the stability problem will disappear.The regression analysis results conducted in accordance with ADF unit-root test results are not realistic and reveal the risk of the availability of spurious regression amongst the variables. In time-series with stability problem, the existence of the relation will be tried to be determined by GCA (Granger Causality Analysis). GCA test is described as "if having information about past values of $\mathrm{X}$ values enables forecasts $\mathrm{Y}$ in a more certain way, $\mathrm{X}$ variable is the cause of $\mathrm{Y}$ variable in Granger sense" [21]. Standard Granger analysis is a general approach in determination of causality relation between two or more variables [4]

Table 6: GCA Statistics Results (With feed prices)

\begin{tabular}{|c|c|c|c|}
\hline \multicolumn{4}{|c|}{ VAR GrangerCausality/BlockExogeneityWaldTests } \\
\hline \multirow{2}{*}{\multicolumn{4}{|c|}{ Date: $03 / 07 / 16 \quad$ Time: $14: 54$}} \\
\hline Sample: 2010M01 2015M12 & & & \\
\hline \multicolumn{4}{|c|}{ Includedobservations: 71} \\
\hline \multicolumn{4}{|c|}{ Dependentvariable: LSUT } \\
\hline Excluded & Chi-sq & $\mathrm{df}$ & Prob. \\
\hline LYEM & 0.732688 & 1 & 0.3920 \\
\hline LSOYA & 1.587493 & 1 & 0.2077 \\
\hline LMISIR & 2.279368 & 1 & 0.1311 \\
\hline LBUGDAY & 2.464550 & 1 & 0.1164 \\
\hline LARPA & 2.194454 & 1 & 0.1385 \\
\hline All & 14.96679 & 5 & 0.0105 \\
\hline
\end{tabular}

According to GCA results, feed price movements are not the cause of milk price movements $(\mathrm{P}>0,05)$. Depending on that, milk prices move independently from feed prices and there is not a significant relation between them. The relation between milk prices that are not affected by micro determinants, ppi and USD \$ that are accepted as macro determinants must be examined, too. For that reason, GCA test was conducted and results are presented in Table 7. 
Table-7: GCA Statistics Results (with macro determinants)

\begin{tabular}{|c|c|c|c|}
\hline \multicolumn{4}{|c|}{ VAR GrangerCausality/BlockExogeneityWaldTests } \\
\hline \multicolumn{4}{|c|}{ Date: $03 / 07 / 16 \quad$ Time: $15: 20$} \\
\hline \multicolumn{4}{|c|}{ Sample: 2010M01 2015M12 } \\
\hline \multicolumn{4}{|c|}{ Includedobservations: 71} \\
\hline \multicolumn{4}{|c|}{ Dependentvariable: LSUT } \\
\hline Excluded & Chi-sq & $\mathrm{df}$ & Prob. \\
\hline LENF & 0.465045 & 2 & 0.7925 \\
\hline LDOLAR & 1.698154 & 2 & 0.4278 \\
\hline All & 9.688488 & 2 & 0.0079 \\
\hline
\end{tabular}

GCA test was carried out between milk price and ppi and USD \$ which are considered as macro determinants and in line with the results, it was concluded that ppi and $\$$ are not the causes of milk prices $(\mathrm{p}>0,05)$. Accordingly, milk prices act independently from $\$$ and ppi values and there is no significant relation between the two. The fact that the model did not introduce expected results as a result of the tests conducted sets forth the existence of structural breaks on the model. These structural breaks are described as temporary and permanent changes in the regression graphic due to various reasons like economic crisis in time-series, technological changes [11] There exist numerous tests to determine the structural breaks, however, because clear explanation of break times and reliability level in these tests are high, Cusum of Square tests were conducted. Using the squares from consecutive residuals in Cusum of Square test, it is examined if coefficients before the structural breaks affect coefficients after the structural breaks. And if the interaction of the coefficients between the periods is confirmed, the existence of a structural break is accepted [11]

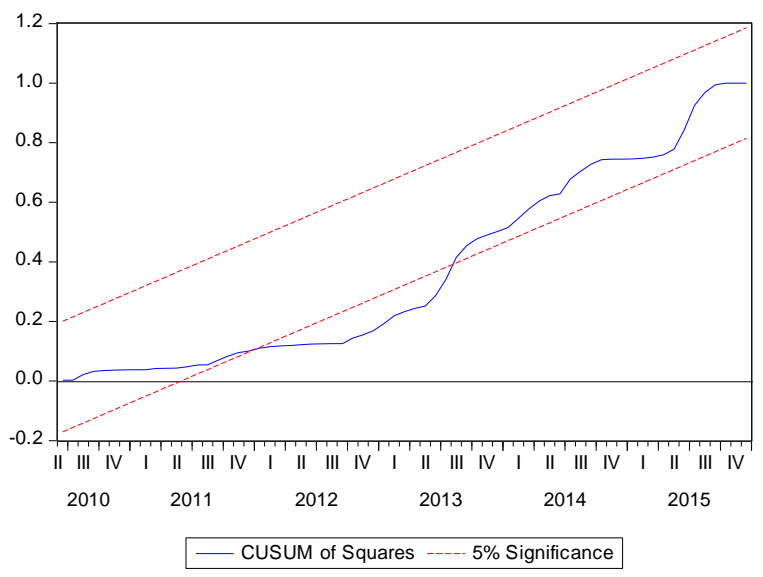

According to the structural break test results conducted, a structural break was detected between 2011 $12 \mathrm{~m}$ and $2013-8 \mathrm{~m}$ periods. A contraction is observed in milk/feed parity in the periods that disrupt the general structure of the model created. In other periods, on the other hand, variables in the model were identified as compatible in general.

\section{Conclusions And Recommendations}

No relation was found between milk prices and concentrate feed, corn, barley, soy, coarse wheat prices in single-equation model created by using monthly-data between the years 2010-2015 in Turkey. In Cusum of Square structural break tests that were carried out with the same data, a structural break between $12 \mathrm{~m}$ and 2013 $8 \mathrm{~m}$ was ascertained. In the direction of these findings, concentrate feed, corn, soy, barley and coarse wheat prices that are important expenses for milk producers do not affect milk prices. Similarly, milk prices act independently from ppi and \$ values. Changes in international milk supply and demand in constitution of milk prices were identified as main determinants in the study. Depending on these findings, milk producers undergo not only micro risks but also global risks.

Milk producers may face with working capital problem depending on prime costs and avoid of longterm financial plans. Milk prices are determined by the National Dairy Council in Turkey. It is understood that while determining milk prices, the NDC does not take the financial structure of variables partaking in the research model into consideration. Based on financial and economic risks specified in the study, it is possible that milk producers relinquish from milk supply. Depending on milk supply decrease, facing the threats specified below is likely;

- Milk used as raw material in dairy industry will bring new problems in its wake such as employment depending on the contraction of the sector, probable decrease in milk supply and high input costs. 
- Decrease in national milk supply will increase foreign trade deficit depending on import increase to be able to meet domestic milk demand, while, on the other side, contracting export volume of Turkey that has a significant share in the world milk producers.

In order to be able to eliminate the threats determined;

While determining milk sale prices, the NDC needs to take account of dynamic price changes of expenditure items to be able to optimum manage working capitals of milk producers. Therefore, milk producers in the NDC must be more active and is required to create an organized structure. For that reason, it is essential for milk producer unions and cooperatives to become more prevalent and hence transform the market into an actuator role.

- Now that the most important element that determines milk prices in Turkey is identified as global supply and demand acts, promotional activities regarding the increase of milk consumption in the domestic market must be augmented, foreign market must be diversified and therefore supply and demand balance must be preserved. Also, to enhance milk supply flexibility, as well as producing milk with long shelf life and high value-added, disorganized milk collection centres must be coordinated to avail producers in optimum numbers, cold storage depots that are close to these centres must be established and hence long-term advantageous products will be procured.

- While milk producers experience problems about not getting higher milk sale prices in spite of the increase in costs, dairy product companies take short-term advantages from that situation. They achieve higher profits selling processed milk that they have bought in relevant costs. The most important problem here, however, will appear in the long run. Especially producers that do not make cost planning and whose profit values decrease year by year will reduce milk production or withdraw from the sector or use their animals for meat production.

[1] Bars T., Akbay C., Kahramanmaraş İlinde Süt ve Süt Ürünleri İşleyen Mandıra İşletmelerinin Yapısal Analizi, Kahramanmaraş Sütcü İmam University, 16 (2), pp.9-20

[2] Boran, Ş., Süt Ve Süt Ürünleri Sektörüne Genel Bakış, İzmir Ticaret Odası Ar\&Ge Bülteni, June.2010

[3] Delgado C. L., "Rising Consumption of Meat and Milk in Developing Countries Has Created a New Food Revolution", The American Society for Nutritional Sciences , November 1, vol. 133 no. 11 3907S-3910S , 2003

[4] Dhamala M, Rangarajan G, Ding MZ. 2008 Estimating Granger causality from Fourier and wavelet transforms of time series data. Physical Review Letters, 100, 018701. 2008

[5] ESK, 2014 Meat And Dairy Authority Sectoral Assessment Report 2014 http://tarim.kalkinma.gov.tr/wp-

[6] content/uploads/2015/12/2014 (April 2016)

[7] FAOSTAT, http://faostat3.fao.org/browse/Q/QL/E (May 2016)

[8] FAO (a) http://www.fao.org/agriculture/dairy-gateway/milk-production/en (April 2016)

[9] FAO (b) http://www.fao.org/agriculture/dairy-gateway/milk-and-milk-products/en ( March 2016)

[10] FAO , "FAO Statistical Pocketbook", Food and Agriculture Organization of the United Nations, Rome, ISBN 97892-5-

[11] 108802-9

[12] Gujarati, D.N., Basic Econometrics, (3rd Ed., Literatur Press., Istanbul.)

[13] Güris, S., Çağlayan , E. ve Güriş, B. EViews ile Temel Ekonometri, ( Der Yayınları: 411, İstanbul,2013)

[14] IDF, The World Dairy Situation, Bullet Of The International Dairy Federation 470 Belgium

[15] IFCN, The Dairy Research Network, "Dairy Report 2015 For A Beter Understanding Of The Dairy World" , ISSN

[16] 1610-434X 2015

[17] Granger C.W.J., Newbold P. Spurious Regression in Econometrics, Journal of Econometrics 2, 111-120, 1974

[18] LACTODATA, Statistics, A Milk SA Publication Compiled By The Milk Producers Organizastion, VoL $18 \bullet$ No 1 -

[19] May,2015

[20] Lestari D.A., Abdullah L.,Comparative Study of Milk Production and Feed Efficiency Based on Farmers Best

[21] Practices and National Research Council, Media Peternakan, August 2015, 38(2):110-117 DOI: 10.5398/medpet, 2015

[22] Mccarthy O., Dairy, Agricultural Commodities. December Quarter, Vol. 4 Issue 4, p104-110, 2014

[23] OECD, "Food and Agriculture Organization of the United Nations" OECD-FAO Agricultural Outlook, OECD Publishing, Paris, 2015

[24] PMMI, Executive Summary and Industry Perspective, 2013 Dairy Industry - A Market Assessment Executive

[25] Summary, 2013

[26] SETB I R, http://www.setbir.org.tr/istatistikler/ig-sut-yem-paritesi (April, 2016)

[27] TAKIM, A., Türkiye'de GSYİH ile İhracat Arasındaki İlişki : Granger Nedensellik Testi, Atatürk Üniversitesi Sosyal Bilimler Enstitüsü Dergisi 14 (2): 1-16., 2010

[28] TU I K, http://www.tuik.gov.tr/PreTablo.do?alt_id=1002 ( May, 2016)

[29] TÜRK I YEM-B İ R,, http://www.yem.org.tr ( April 2016)

[30] TEPGEM , Tarımsal Veriler, 2015, http://www.tarim.gov.tr/Belgeler/SagMenuVeriler/ Tarimsal _Veriler.pdf ,

[31] Terin M, Bilgiç A., Güler İ ., Okan Y.F., Türkiye'de Süt Ürünleri Tüketim Harcamalarına Etki Eden Faktörlerin 
[32] Analizi: Çoklu Heckman Örneklem Seçicilik Sistem Yaklaşımı, Tarım Bilimleri Dergisi, sayı 21, 500-515, 2015

[33] NDS, (2014), Dünya ve Türkiye'de Süt Sektör İstatistikleri 2014, (Ulusal Süt Konseyi yayınları, May., Ankara 2014)

[34] Wiley A. S. "Milk for Growth: Global and Local Meanings of Milk Consumption in China, India, and the United States", Food and Foodways, 19:1-2, 11-33, ISSN: 0740-9710

[35] Wolf. C. A. , "Understanding The Milk-To-Feed Price Ratio As A Proxy For Dairy Farm Profitability", American

[36] Dairy Science Association, Science, October, Vol. 93 No. 10, p. 4942-4948, 2010

[37] Vural,H., Fidan,H., (2007), “Türkiye'de Hayvansal Üretim ve Hayvancılık İsletmelerinin Özellikleri”,Tarım Ekonomisi Dergisi 13(2) : 49-59, 2007 